\title{
Biological activity of Serratia marcescens cytotoxin
}

G.V. Carbonell ${ }^{1}$, C.R.N. Amorim ${ }^{1}$, M.T. Furumura ${ }^{1}$, A.L.C. Darini ${ }^{2}$,

B.A.L. Fonseca ${ }^{3}$ and T. Yano ${ }^{1}$

\author{
${ }^{1}$ Departamento de Microbiologia e Imunologia, Instituto de Biologia, \\ Universidade Estadual de Campinas, Campinas, SP, Brasil \\ ${ }^{2}$ Departamento de Análises Clínicas, Toxicológicas e Bromatológicas, \\ Faculdade de Ciências Farmacêuticas de Ribeirão Preto, \\ Universidade de São Paulo, Ribeirão Preto, SP, Brasil \\ ${ }^{3}$ Departamento de Clínica Médica, Faculdade de Medicina de Ribeirão Preto, \\ Universidade de São Paulo, Ribeirão Preto, SP, Brasil
}

\section{Correspondence}

G.V. Carbonell

Departamento de Microbiologia e

Imunologia

Instituto de Biologia, UNICAMP

13083-970 Campinas, SP

Brasil

Fax: +55-19-3788-7191

E-mail: gleize@yahoo.com

Research supported by FAPESP.

Received July 2, 2001

Accepted October 21, 2002

\begin{abstract}
Serratia marcescens cytotoxin was purified to homogeneity by ionexchange chromatography on a DEAE Sepharose Fast Flow column, followed by gel filtration chromatography on a Sephadex G100 column. The molecular mass of the cytotoxin was estimated to be about $50 \mathrm{kDa}$. Some biological properties of the cytotoxin were analyzed and compared with well-characterized toxins, such as VT1, VT2 and CNF from Escherichia coli and hemolysin produced by S. marcescens. The sensitivity of the cell lines CHO, HeLa, HEp-2, Vero, BHK21, MA 104 and J774 to the cytotoxin was determined by the cell viability assay using neutral red. CHO and HEp-2 were highly sensitive, with massive cellular death after $1 \mathrm{~h}$ of treatment, followed by BHK-21, HeLa, Vero and J774 cells, while MA 104 was insensitive to the toxin. Cytotoxin induced morphological changes such as cell rounding with cytoplasmic retraction and nuclear compactation which were evident $15 \mathrm{~min}$ after the addition of cytotoxin. The cytotoxic assays show that $15 \mathrm{~min}$ of treatment with the cytotoxin induced irreversible intoxication of the cells, determined by loss of cell viability. Concentrations of $2 \mathrm{CD}_{50}(0.56 \mu \mathrm{g} / \mathrm{ml})$ of purified cytotoxin did not present any hemolytic activity, showing that the cytotoxin is distinct from $S$. marcescens hemolysin. Antisera prepared against $S$. marcescens cytotoxin did not neutralize the cytotoxic activity of VT1, VT2 or CNF toxin, indicating that these toxins do not share antigenic determinants with cytotoxin. Moreover, we did not detect gene sequences for any of these toxins in $S$. marcescens by PCR assay. These results suggest that $S$. marcescens cytotoxin is not related to any of these toxins from E. coli.
\end{abstract}

\section{Introduction}

Serratia marcescens has been considered to be an important nosocomial pathogen, responsible for endemic and epidemic infections, especially in newborns and patients submitted to invasive procedures (1-4).
Key words

- Cell culture

- Biological activity

- Serratia marcescens

- Cytotoxin

- Virulence factors 
serotype. Moreover, this cytotoxic activity is not mediated by plasmids. The S. marcescens toxin is extracellular and heat labile, and optimal culture conditions were incubation at temperatures ranging from 30 to $37^{\circ} \mathrm{C}$ for $24 \mathrm{~h}$ under shaking in medium adjusted to $\mathrm{pH} 8.5$ (6).

Recently, it was shown that the hemolysin of $S$. marcescens induces cytotoxic effects on human epithelial cells, characterized by vacuolization with subsequent cell lysis (7). The cytopathic effects of the $S$. marcescens cytotoxin correspond to cell rounding followed by gradual destruction of the monolayer, as observed by inverted microscopy (5). This technique is routinely used to assess cytotoxicity in cell culture; however, it lacks sensitivity for detecting more details about early events of the cell injury process. Thus, it is still unclear whether the cytotoxin causes vacuolization and cell lysis.

We report here the purification of the $S$. marcescens cytotoxin and compare its biological characteristics with those of other well-characterized toxins.

\section{Material and Methods}

\section{Cytotoxin purification}

A $0.5-\mathrm{ml}$ pre-culture of $S$. marcescens (6) was inoculated into $500 \mathrm{ml}$ Davis minimal medium (8) in a 1-liter Erlenmeyer flask with shaking at $150 \mathrm{rpm}$ and incubated at $37^{\circ} \mathrm{C}$ for $18-24 \mathrm{~h}$. Six liters of culture from 12 such flasks was centrifuged at $10,000 \mathrm{~g}$ for $15 \mathrm{~min}$ at $4^{\circ} \mathrm{C}$ and ammonium sulfate was added slowly to the culture supernatant to $80 \%$ saturation. After centrifugation at 10,000 $g$ for $15 \mathrm{~min}$ at $4^{\circ} \mathrm{C}$, the pellet collected was dissolved in $25 \mathrm{mM}$ Tris-HCl, $\mathrm{pH} 7.0$, followed by exhaustive dialysis against the same buffer. The preparation was applied to a DEAE Sepharose Fast Flow column (3.0 x $9.0 \mathrm{~cm}$; Pharmacia LKB Biotechnology, Uppsala, Sweden) equilibrated with $25 \mathrm{mM}$ Tris- $\mathrm{HCl}$ buffer, $\mathrm{pH} \mathrm{7.0,} \mathrm{and} \mathrm{the} \mathrm{cytotoxin}$ was eluted (5-ml fractions) with the same buffer containing $0.1 \mathrm{M} \mathrm{NaCl}$. Fractions with toxicity were pooled, concentrated to $5 \mathrm{ml}$ by ultrafiltration through a PM 10 membrane (Amicon Corp., Lexington, MA, USA) and applied to a Sephadex G100 column (2.5 x $68 \mathrm{~cm}$; Pharmacia) equilibrated and eluted (2.5-ml fractions) with $25 \mathrm{mM}$ Tris- $\mathrm{HCl}$ buffer containing $0.15 \mathrm{M} \mathrm{NaCl}, \mathrm{pH}$ 7.0. Fractions with the highest cytotoxic activity were pooled and stored at $-70^{\circ} \mathrm{C}$ until use. The total protein concentration was determined by the method of Bradford using reagents from BioRad (Hercules, CA, USA) and serum albumin as standard (9).

\section{Molecular mass estimation by gel filtration chromatography}

The molecular mass of the cytotoxin was estimated by gel filtration on a Superdex 200 HR column (Pharmacia). A 0.1-ml portion of purified cytotoxin was applied to the column equilibrated with $25 \mathrm{mM}$ Tris- $\mathrm{HCl}$ buffer, $\mathrm{pH} 7.0$, and eluted at $0.25 \mathrm{ml} / \mathrm{min}$ in an HPLC system (Shimadzu, Kyoto, Japan). Absorbance of the cytotoxin was measured at $280 \mathrm{~nm}$ and the material was collected and assayed for cytotoxicity on Chinese hamster ovary (CHO) cells. The molecular mass of the cytotoxin was estimated by comparing its elution volume with those of calibration standards such as ribonuclease $\mathrm{A}(13.7 \mathrm{kDa})$, chymotrypsinogen A (25 kDa), ovalbumin (43 kDa), albumin (67 kDa) and blue dextran $2000(>100 \mathrm{kDa})(10)$.

\section{Gel electrophoresis}

The purified cytotoxin $(30 \mu \mathrm{g} / \mathrm{ml})$ was assessed for purity on $8 \%$ silver-stained sodium dodecyl sulfate (SDS)-polyacrylamide gel (11).

\section{Cell lines and cytotoxic assays}

Human cervical carcinoma (HeLa), Vero, 
human epidermoid carcinoma (HEp-2), baby hamster kidney (BHK-21), CHO, mouse tumor macrophage (J774) and monkey kidney (MA 104) cells, all obtained from the American Type Culture Collection (Rockville, MD, USA), were maintained in tissue culture flasks with Eagle's modified essential medium (Gibco, BRL, São Paulo, SP, Brazil) supplemented with $10 \%$ fetal calf serum, and $0.75 \mathrm{mM}$ L-glutamine. The $\mathrm{J} 774$ cells were cultivated in RPMI medium (Gibco) under the same conditions as described above. The cytotoxicity assays were performed as described in Ref. 6. Briefly, after formation of a cell monolayer, the medium was removed from each well and replaced with fresh medium without serum and containing the cytotoxin. The plates were incubated in the presence of $5 \% \mathrm{CO}_{2}$ at $37^{\circ} \mathrm{C}$. The cell monolayer morphology was observed daily under an inverted microscope in order to detect the presence of any cytopathic effect.

\section{Determination of cell viability and $C_{50}$}

In order to compare the sensitivities of the cell lines to $S$. marcescens cytotoxin, cell viability after the cytotoxic assay was quantified by the neutral red cytotoxicity assay (6). The concentration of toxin that killed $50 \%$ of $\mathrm{CHO}$ cells $\left(\mathrm{CD}_{50}\right)$ was calculated as described in Ref. 12.

\section{Morphological changes}

The $\mathrm{CHO}$ cells were grown on coverslips placed inside 24-well plates using $1 \mathrm{ml}$ of cell suspension $\left(1 \times 10^{4}\right.$ cells $\left./ \mathrm{ml}\right)$ per well and the plates were incubated at $37^{\circ} \mathrm{C}$ in the presence of $5 \% \mathrm{CO}_{2}$. After $24 \mathrm{~h}$, the culture medium was aspirated and replaced with 1 $\mathrm{ml}$ of fresh medium and a $2 \mathrm{CD}_{50}$ dose of cytotoxin was added to each well. At timedefined intervals, the coverslips were washed with phosphate-buffered saline (PBS) and fixed in $10 \%$ formaldehyde solution in PBS for $1 \mathrm{~h}$. The coverslips were then washed with distilled water and stained with $0.025 \%$ toluidine blue, $\mathrm{pH} 4.0$, as described by Mello and Vidal (13). The coverslips were washed with distilled water, air dried, cleared in xylene and mounted on slides using Entellan (Merck, Darmstadt, Germany). The cellular alterations were observed with an Axioskop microscope (Nikon, Tokyo, Japan).

\section{Antiserum production}

Aliquots of $50 \mu 1$ of a purified cytotoxin preparation $(75 \mu \mathrm{g}$ of protein per $\mathrm{ml})$ were emulsified in an equal volume of Freund's complete adjuvant and injected via the inguinal node, with subsequent injections in incomplete adjuvant after 2 weeks. Animals were bled and the cytotoxicity-neutralizing capacity of the sera was tested.

\section{Seroneutralization assays}

In order to determine whether $S$. marcescens cytotoxin antiserum could neutralize the cytotoxicity of VT1, VT2 or cytotoxic necrotizing factor (CNF) produced by $E$. coli, seroneutralization assays were carried out (14). Antisera produced in rabbits against purified cytotoxin of $S$. marcescens were serially diluted in Eagle's medium and mixed with $1 / 40$ dilution of the test toxins. The mixtures were incubated for $1 \mathrm{~h}$ at $37^{\circ} \mathrm{C}$, applied to Vero cells and incubated for $72 \mathrm{~h}$ at $37^{\circ} \mathrm{C}$. The plates were examined microscopically on a daily basis for the appearance of cytopathogenicity. Negative controls with preimmune serum were also included.

\section{Hemolysis assays}

The hemolytic activity of the purified cytotoxin was assayed as previously described (7). A $2 \mathrm{CD}_{50}$ dose $(0.56 \mu \mathrm{g} / \mathrm{ml})$ of cytotoxin was serially diluted (base 2) in $0.9 \% \mathrm{NaCl}$ and $100-\mu 1$ aliquots of each dilu- 
tion were mixed with $1 \mathrm{ml}$ of erythrocyte suspension and incubated for $30 \mathrm{~min}$ at $30^{\circ} \mathrm{C}$. The mixture was then centrifuged for $3 \mathrm{~min}$ at 2,500 rpm to remove unlysed erythrocytes and cell debris. The absorbance of the supernatants containing released hemoglobin was measured at $405 \mathrm{~nm}$. Results were compared with total lysis $(100 \%)$ caused by SDS used
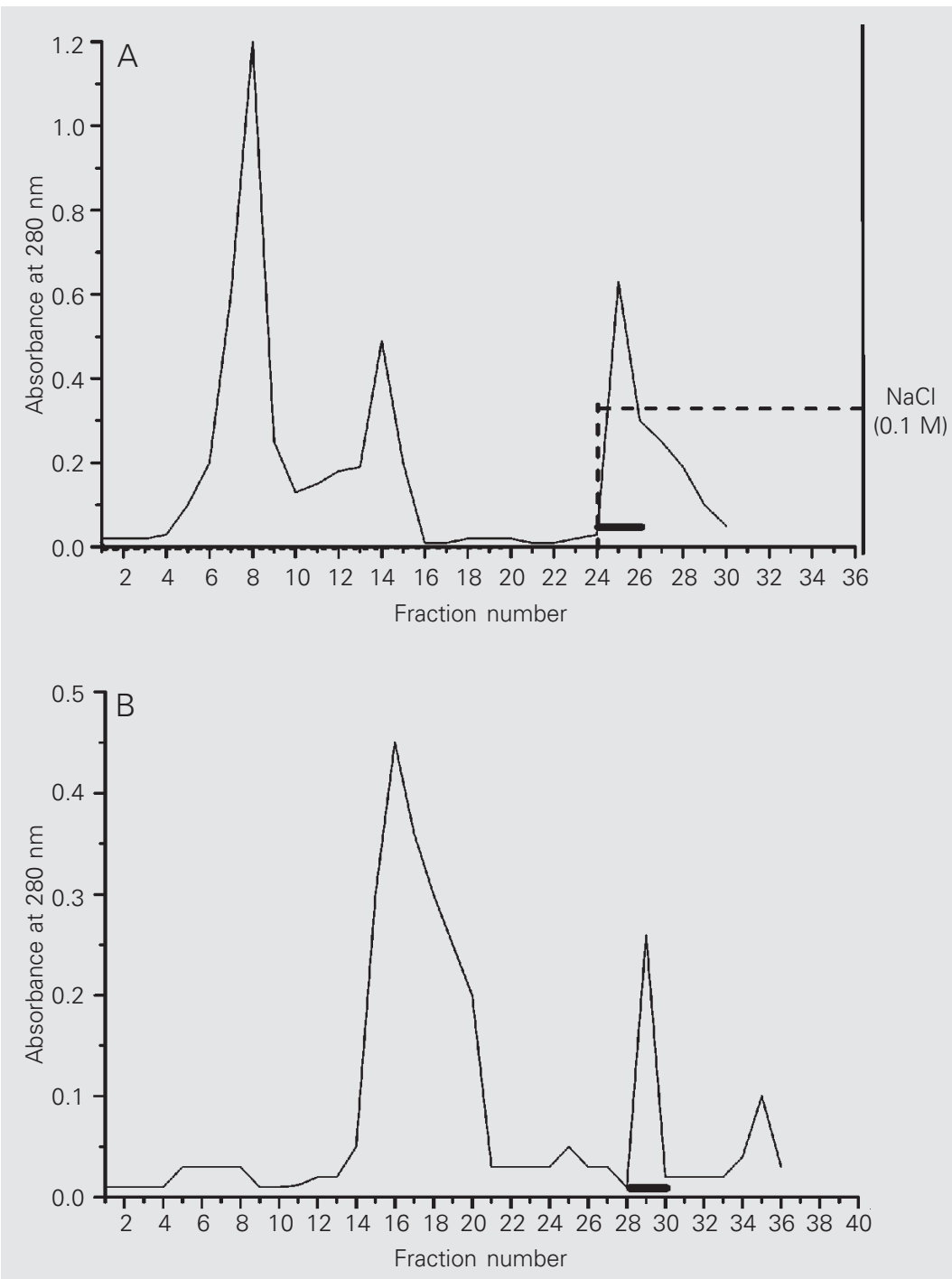

Figure 1. A, DEAE Sepharose Fast Flow column chromatography. A crude sample was applied to a DEAE Sepharose Fast Flow column equilibrated with $25 \mathrm{mM}$ Tris-HCl buffer, $\mathrm{pH}$ 7.0. Fractions with cytotoxic activity $(5 \mathrm{ml})$ were eluted with a nonlinear gradient of $0.1 \mathrm{M}$ $\mathrm{NaCl}$ in the same buffer. The horizontal bar indicates the fractions pooled for subsequent purification. B, Sephadex G100 column chromatography. The cytotoxic fractions $(5 \mathrm{ml})$ obtained from the DEAE Sepharose column were applied to a Sephadex G100 column equilibrated with $25 \mathrm{mM}$ Tris- $\mathrm{HCl}$ buffer, $\mathrm{pH} 7.0$, containing $0.15 \mathrm{M} \mathrm{NaCl}$. The horizontal bar indicates the fractions with cytotoxic activity. as control.

\section{Toxin gene sequence determination by} genotypic analysis (PCR)

The $S$. marcescens strain was screened for the presence of gene sequences of toxins from $E$. coli using primers for VT1 (ST-I), VT2 (ST-II) (15) and CNF (16). Bacterial DNA to be amplified was released from the organism by boiling. The reactions were performed as previously described (17) using 2 $\mu \mathrm{l}$ dNTP solution containing $20 \mathrm{mM}$ of each nucleotide, $1 \mu \mathrm{l}$ Taq DNA polymerase ( $1 \mathrm{U} /$ $\mu \mathrm{l}), 3 \mu \mathrm{l} 5 \mu \mathrm{M} \mathrm{MgCl}_{2}, 5 \mu \mathrm{l}$ PCR buffer, $5 \mu \mathrm{l}$ DNA, $1 \mu$ of each primer ( $50 \mathrm{pmol})$, and 35 $\mu 1$ sterile Milli-Q water. The solutions were pre-heated without the enzyme at $94^{\circ} \mathrm{C} / 10$ min and submitted to 30 cycles (GeneAmp PCR System 9700, Perkin Elmer, Foster City, CA, USA) of $94^{\circ} \mathrm{C} / 2 \mathrm{~min}, 50^{\circ} \mathrm{C} / 2 \mathrm{~min}$ and $72^{\circ} \mathrm{C} / 1 \mathrm{~min}(\mathrm{VT} 2), 94^{\circ} \mathrm{C} / 2 \mathrm{~min}, 57^{\circ} \mathrm{C} / 2 \mathrm{~min}$ and $72^{\circ} \mathrm{C} / 1 \mathrm{~min}$ (ST-I and CNF); after these cycles they were submitted to $72^{\circ} \mathrm{C} / 7 \mathrm{~min}$. PCR products were analyzed by $2 \%$ horizontal agarose gel electrophoresis with ethidium bromide staining under UV light.

\section{Results}

\section{Cytotoxin purification}

The crude cytotoxin preparations were initially subjected to ion-exchange chromatography on a DEAE Sepharose Fast Flow column. The column was eluted with $500 \mathrm{ml}$ of $25 \mathrm{mM}$ Tris-HCl buffer at a flow rate of 1 $\mathrm{ml} / \mathrm{min}$, and the fractions containing cytotoxic activity were eluted with the same buffer containing $0.1 \mathrm{M} \mathrm{NaCl}$ (Figure 1A, horizontal bar). The cytotoxin was subsequently chromatographed on a Sephadex G100 gel filtration column equilibrated with $25 \mathrm{mM}$ Tris- $\mathrm{HCl}$ buffer containing $0.15 \mathrm{M}$ $\mathrm{NaCl}$. Cytotoxic activity was eluted in the third peak (Figure 1B, horizontal bar). Cytotoxin obtained at this stage presented a single 
protein band by SDS electrophoresis (Figure 2). The cytotoxin peak was eluted between the positions for bovine serum albumin and ovalbumin, corresponding to an apparent molecular mass of 47 to $50 \mathrm{kDa}$ on the calibration curve.

\section{Cytotoxicity and cell viability assays}

Among the cell lines tested, $\mathrm{CHO}, \mathrm{HeLa}$, HEp-2, Vero, BHK-21 and J774 were susceptible to $S$. marcescens cytotoxin and only MA 104 cells were resistant. Although the susceptible cell lines showed similar morphological changes when exposed to cytotoxin, the cells were not affected to the same extent after exposure for a specific time. The highest sensitivity was observed with $\mathrm{CHO}$ and HEp-2 cells, with the cytopathic effect starting as early as 15 min after incubation with toxin and resulting in the destruction of the monolayer within 1-2 h (Figure 3). The BHK-21, HeLa, J774 and Vero cells showed monolayer destruction after $24 \mathrm{~h}$, as determined by the viability assays. Thus, the $\mathrm{CHO}$ cells were used in all experiments for the characterization of the cytotoxin. The $\mathrm{CD}_{50}$ of the cytotoxin is defined as the highest concentration of the sample that killed 50\% of the $\mathrm{CHO}$ cells after $24 \mathrm{~h}$. The purified cytotoxin had a $\mathrm{CD}_{50}$ of $0.28 \mu \mathrm{g} / \mathrm{ml}$.

\section{Morphological changes}

Morphological changes induced by the cytotoxin were studied in $\mathrm{CHO}$ cells stained with toluidine blue after different incubation periods. The first observable changes were evident about 15 min after the addition of the cytotoxin. The cytoplasm started to retract and the cells became rounded, with progressive nuclear compactation and extensive surface blebbing being observed after $1 \mathrm{~h}$ (Figure 4B). The morphological changes induced by the cytotoxin were then compared with $S$. marcescens hemolysin and VT1, VT2 and CNF from E. coli (Table 1).
A

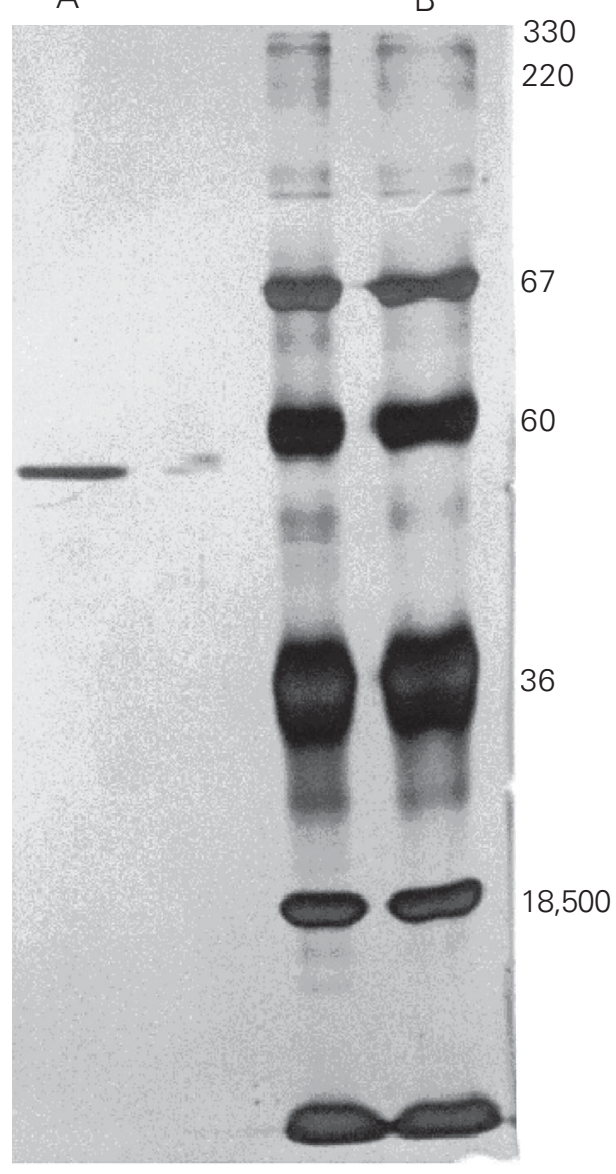

Figure 2. Analysis of Serratia marcescens cytotoxin by SDSPAGE using silver staining. Lane A, Cytotoxic fraction obtained from a Sephadex G100 column $(30 \mu \mathrm{g} / \mathrm{ml})$; lane $B$, molecular weight markers.

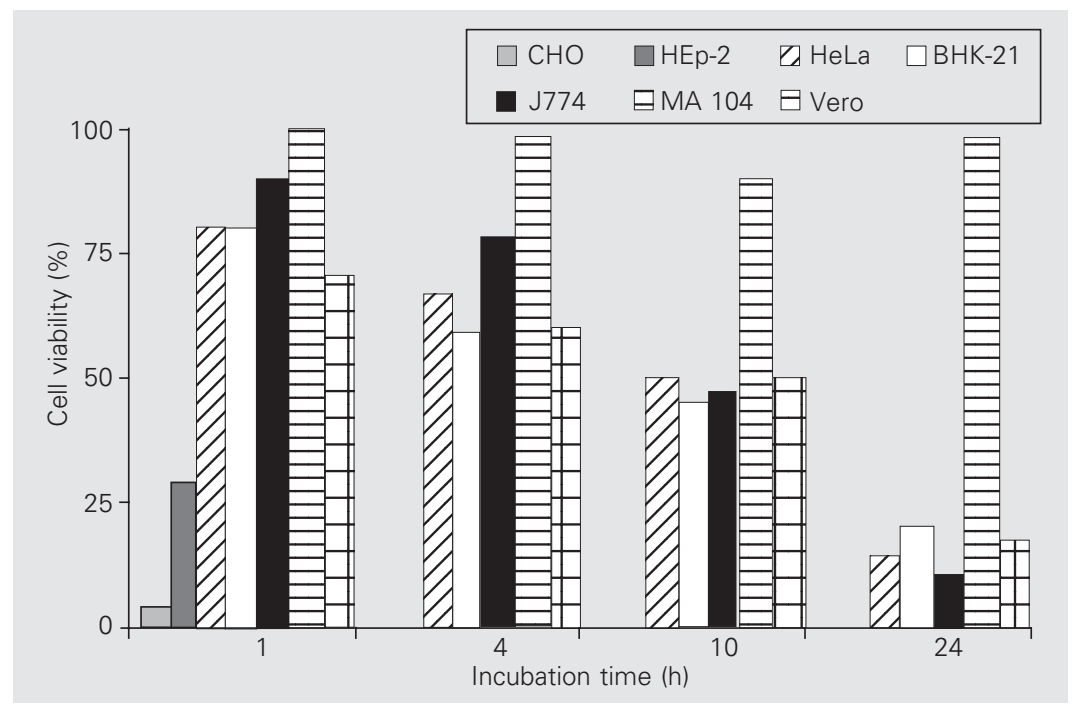

Figure 3. Response of the CHO, HEp-2, HeLa, BHK-21, Vero, MA 104 and $\mathrm{J} 774$ cell lines after different incubation periods with a $2 \mathrm{CD}_{50}$ dose $(0.56 \mu \mathrm{g} / \mathrm{ml})$ of purified Serratia marcescens cytotoxin. Cell viability was measured by neutral red assay. 
Figure 4. Morphological changes induced by purified Serratia marcescens cytotoxin (2 $\mathrm{CD}_{50}$ dose) in $\mathrm{CHO}$ cells stained with toluidin blue (100X). A, Typical morphology of the control cells; $B$, cytoplasmic retraction, nuclear compactation and cytoplasmic blebbing (arrowheads) after $30 \mathrm{~min}$ of treatment.
S. marcescens cytotoxin did not show assay, even when treated with crude cytotoxin preparations $\left(2 \mathrm{CD}_{50}\right.$ dose or $0.56 \mu \mathrm{g} /$ $\mathrm{ml})$.

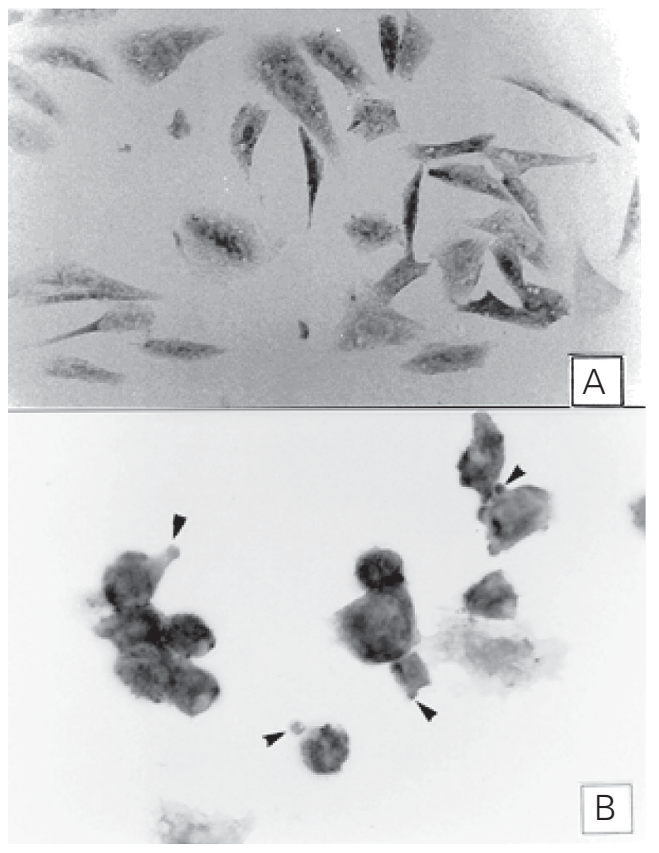

Hemolysis assays hemolytic activity in the liquid hemolytic

\section{Serum neutralization assays}

At higher concentrations of antitoxin serum, i.e., lower dilution, the morphological changes induced by VT1, VT2 and CNF toxins from E. coli on Vero cells were clearly evident after $24 \mathrm{~h}$. The results of neutralization studies showed that antiserum against $S$. marcescens cytotoxin did not neutralize the biological activity of these toxins (Figure 5).

\section{Genotypic analysis (PCR)}

The assays showed that $S$. marcescens isolates do not amplify any detectable fragment, being characterized as negative for amplification by PCR gene sequence for VT1, VT2 and CNF toxins.

\section{Discussion}

The $S$. marcescens cytotoxin used in the present study was purified to homogeneity from a culture supernatant grown in Davis minimal medium (8) by ion-exchange chromatography on a DEAE Sepharose Fast Flow column and submitted to gel filtration on a
Table 1. Characteristics of toxins that were compared with Serratia marcescens cytotoxin in this study.

\begin{tabular}{|c|c|c|c|c|}
\hline Bacterial toxin & Type of effect & Sensitive cell lines* & $\begin{array}{c}\text { Time of cytopathic } \\
\text { effect* }^{*}\end{array}$ & Reference \\
\hline $\begin{array}{l}\text { S. marcescens } \\
\text { cytotoxin }\end{array}$ & $\begin{array}{l}\text { Cell rounding, cytoplasmic } \\
\text { retraction }\end{array}$ & CHO, HEp-2, HeLa & $15 \mathrm{~min}$ & $\begin{array}{l}\text { Present } \\
\text { study }\end{array}$ \\
\hline $\begin{array}{l}\text { S. marcescens } \\
\text { hemolysin }\end{array}$ & Vacuolization, cell lysis & $\begin{array}{l}\text { Erythrocytes, } \\
\text { HeLa, HEp-2 }\end{array}$ & $10 \mathrm{~min}$ & 7 \\
\hline E. coli VT1 & $\begin{array}{l}\text { Round cells with a shriveled } \\
\text { appearance }\end{array}$ & Vero, HeLa & $24 \mathrm{~h}$ & 19 \\
\hline E. coli VT2 & $\begin{array}{l}\text { Round cells with a shriveled } \\
\text { appearance }\end{array}$ & Vero, HeLa & $24 \mathrm{~h}$ & 19 \\
\hline E. coli CNF & $\begin{array}{l}\text { Formation of giant cells, } \\
\text { multinucleation }\end{array}$ & HeLa, Vero & $24 \mathrm{~h}$ & 19 \\
\hline
\end{tabular}

*The most common cells used for the cytotoxicity assays.

${ }^{* *}$ Approximate time for the appearance of a cytopathic effect after toxin addition. 
Sephadex G100 column. The fractions with cytotoxic activity were eluted in the third peak (Figure 1B, horizontal bar) and revealed a single protein band by SDS electrophoresis (Figure 2). The molecular mass of the purified cytotoxin was estimated to be 47 to $50 \mathrm{kDa}$ by gel filtration chromatography. This method is based on a calibration curve using proteins of known molecular masses as markers (10). The results show that the molecular mass of cytotoxin is apparently different from extracellular proteases produced by this bacterium, which have molecular masses of 56, 60 and $73 \mathrm{kDa}$ (18). However, this cytotoxin has not yet been characterized in terms of proteolytic activity.
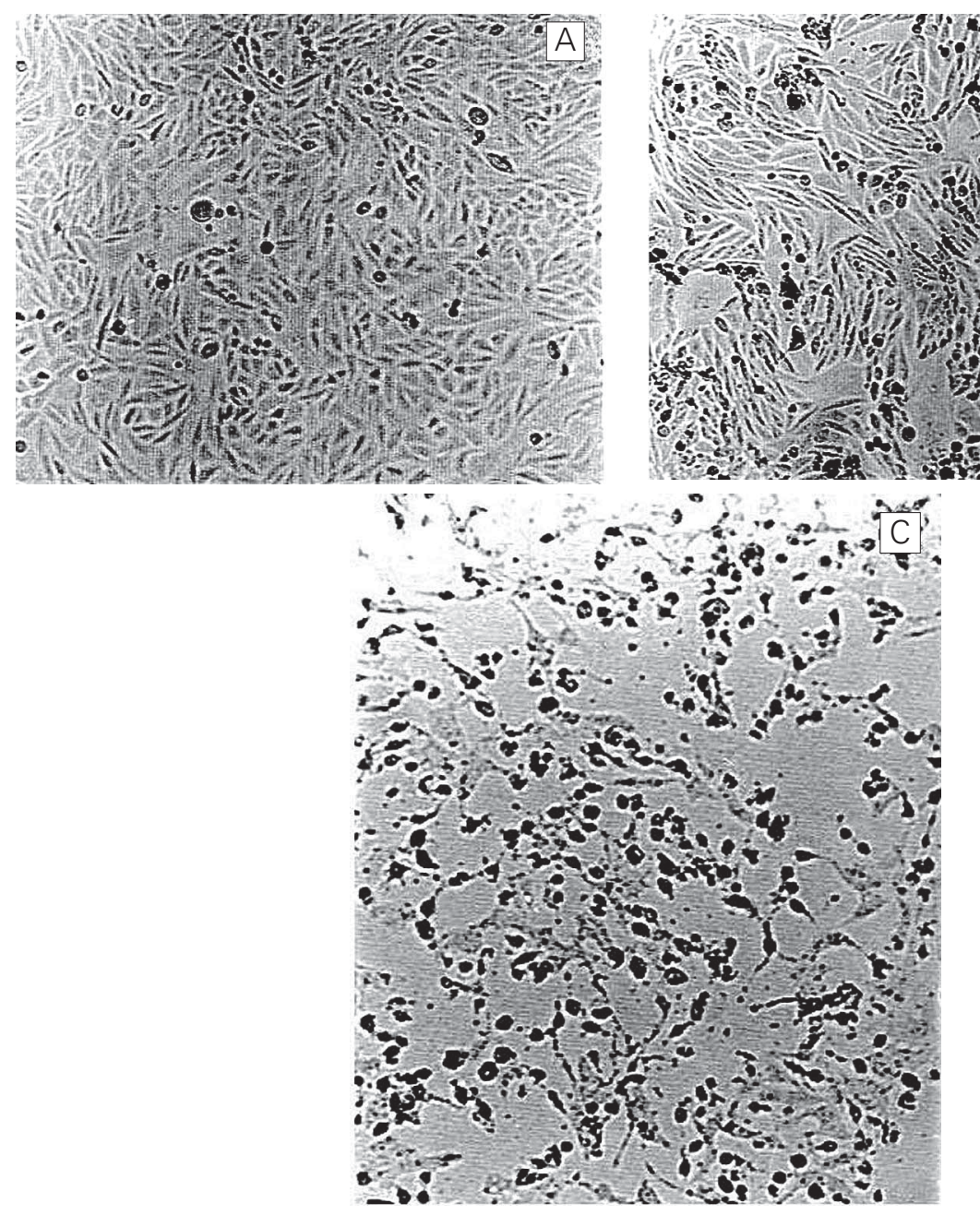

In order to choose a suitable target cell line, we compared the sensitivity of several cell lines to cytotoxin produced by clinical isolates of $S$. marcescens. This represents an important step related to the practical aspects of characterization of the cytotoxin. CHO and HEp-2 cells appeared to be the most sensitive to the toxic effects of $S$. marcescens cytotoxin, followed by BHK-21, HeLa, J774 and Vero cells (Figure 3), while MA 104 cells were resistant to the toxin. Thus, $\mathrm{CHO}$ cells were used as a model to study the details of the mechanism of action of the cytotoxin.

The pattern of morphological changes gives a preliminary idea of the characteristics of the toxin and its mechanism of action

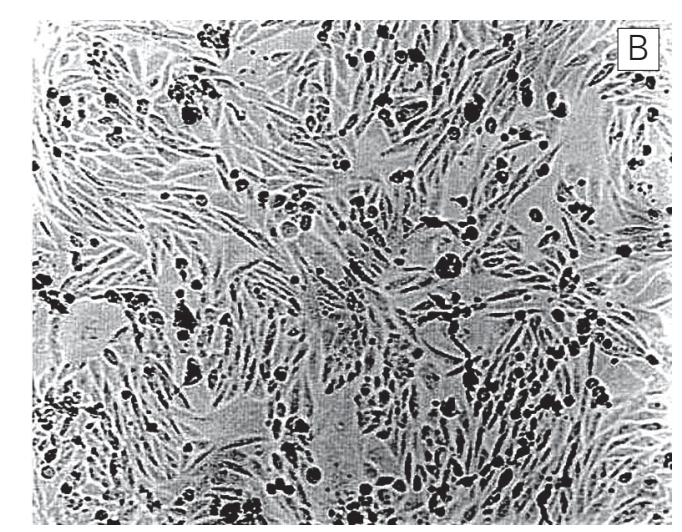

Figure 5. Effects of VT1 and CNF toxins on Vero cells in seroneutralization assays. A, Vero control cells. B, Vero cells that received mixtures of antiserum against Serratia marcescens cytotoxin incubated for $1 \mathrm{~h}$ at $37^{\circ} \mathrm{C}$ with CNF toxin. $C$, Vero cells inoculated with mixtures of antiserum and $\mathrm{VT}$ toxin. 
on the cells. The cells treated with $S$. marcescens cytotoxin lost the typical morphology observed in the untreated cultures (Figure 4A) and showed cell rounding, cytoplasmic retraction, compactation of the nuclei and cytoplasmic blebbing (Figure 4B). The morphological changes induced in cell lines and the time of first observable effects are useful to distinguish the $S$. marcescens cytotoxin from other bacterial toxins, as shown in Table 1. The cell rounding seen in $\mathrm{CHO}$ cells in response to the $S$. marcescens cytotoxin is different from the cell rounding with shriveled appearance induced by VT1 and VT2 or from the giant, multinucleated cells induced by CNF from E. coli (19). The lack of neutralization of cytotoxic activity of VT1, VT2 and CNF by antisera prepared against $S$. marcescens cytotoxin indicates that these toxins do not possess an antigenic relationship. Moreover, cytotoxin-producing S. marcescens was negative when tested for the presence of gene sequences for VT1, VT2 and CNF toxins. The results of all comparative studies showed that cytotoxin is not related to any of the toxins studied.

Almost all strains of $S$. marcescens secrete a hemolysin that lyses all mammalian erythrocytes tested and is cytotoxic to human epithelial cells. The cytopathic effects of hemolysin on HEp-2 cells were characterized by rapid vacuolization $(15 \mathrm{~min})$ followed by lysis after $40 \mathrm{~min}$ (7). These morphological changes observed in cultured cells were clearly distinct from those of cytotoxin, as shown in Table 1. Therefore, the purified cytotoxin did not cause hemolytic activity in liquid assays. This is of particular importance since this study provides clear evidence that the cytotoxin is distinct from $S$. marcescens hemolysin.

\section{Acknowledgments}

We are grateful to the staff of the Laboratory of Microbiology, School of Medicine of Ribeirão Preto, USP, who provided the bacterial strains, and to Ana Stella Menegon Degrossoli for technical assistance.

\section{References}

1. Archibald LK, Manning ML, Bell LM, Banerjee $S$ \& Jarvis WR (1997). Patient density, nurse-to-patient ratio and nosocomial infection risk in a paediatric cardiac intensive care unit. Pediatric Infectious Disease Journal, 16: 1045-1048.

2. Van Ogtrop ML, Van Zoeren-Grobben D, Verbakel-Salomons EMA \& Van Boven CPA (1997). Serratia marcescens infections in neonatal departments: Description of an outbreak and review of the literature. Journal of Hospital Infection, 36: 95-103.

3. Bosi C, Davin-Regli A, Charrel R, Rocca B, Monnet D \& Bollet C (1996). Serratia marcescens nosocomial outbreak due to contamination of hexetidine solution. Journal of Hospital Infection, 33: 217224.

4. Miranda G, Kelly C, Solorzano F, Leanos B, Coria R \& Patterson JE (1996). Use of pulsed-field gel electrophoresis typing to study an outbreak of infection due to Serratia marcescens in a neonatal intensive care unit. Journal of Clinical Microbiology, 34: 3138-3141.

5. Carbonell GV, Alfieri AF, Alfieri AA, Vidotto MC, Levy CE, Darini ALC \& Yanaguita RM (1997). Detection of cytotoxic activity on Vero cells in clinical isolates of Serratia marcescens. Brazilian Journal of Medical and Biological Research, 30: 1291-1298.

6. Carbonell GV, Fonseca BAL, Figueiredo LTM, Darini ALC \& Yanaguita RM (1996). Culture conditions affect cytotoxin production by Serratia marcescens. FEMS Immunology and Medical Microbiology, 16: 299-307.
7. Hertle R, Hilger M, Weingardt-Kocher S \& Walev I (1999). Cytotoxic action of Serratia marcescens hemolysin on human epithelial cells. Infection and Immunity, 67: 817-825.

8. Davis BD \& Minglioli ES (1950). Mutants of Escherichia coli requiring methionine or vitamin B12. Journal of Bacteriology, 60: 17-28.

9. Bradford MM (1976). A rapid method for the quantification of microgram quantities of protein utilizing the principle of protein-dye binding. Analytical Biochemistry, V: 248-254.

10. MacLeod DL, Gyles CL, Valdivieso-Garcia A \& Clarke RC (1991). Physicochemical and biological properties of purified Escherichia coli shiga-like toxin II variant. Infection and Immunity, 59: 1300-1306.

11. Laemmli UK (1970). Cleavage of structural proteins during assembly of the head of bacteriophage T4. Nature, 227: 680-685.

12. Cleary TG, Mathewson JJ, Faris E \& Pickering LK (1985). Shiga-like cytotoxin production by enteropathogenic Escherichia coli serogroups. Infection and Immunity, 47: 335-337.

13. Mello ML \& Vidal B (1980). Práticas em Biologia Celular. Edgard Blucher, Rio de Janeiro, RJ, Brazil, 71.

14. Parreira VR \& Yano $T$ (1998). Cytotoxin produced by Escherichia coli isolated from chickens with swollen head syndrome (SHS). Veterinary Microbiology, 62: 111-119.

15. Ojeniyi B, Ahrens P \& Meyling A (1994). Detection of fimbrial and toxin genes in Escherichia coli and their prevalence in piglets with diarrhoea. The application of colony hybridization assay, polymerase 
chain reaction and phenotypic assays. Journal of Veterinary Medicine. Series B: Infectious Diseases and Veterinary Public Health, 41: 49-59.

16. Blanco M, Blanco JE, Blanco J, Alonso MP, Balsanobre C, Mourino M, Madrid C \& Juarez A (1996). Polymerase chain reaction for detection of Escherichia coli strains producing cytotoxic necrotizing factor type 1 and type 2 (CNF1 and CNF2). Journal of Microbiological Methods, 26: 95-101.

17. Blanco M, Blanco JE, Gonzalez EA, Mora A, Jansen W, Gomes T, Zerbini LF, Yano T, Pestana De Castro AF \& Blanco J (1997). Genes encoding for enterotoxins and verotoxins in porcine Escherichia coli strains belonging to different O:K:H serotypes: relationship with toxic phenotypes. Journal of Clinical Microbiology, 35: 2958-2963.

18. Matsumoto K, Maeda H, Takata K, Kamata R \& Okamura R (1984). Purification and characterization of four proteases from a clinical isolate of Serratia marcescens kums 3958. Journal of Bacteriology, 157: 225-232.

19. Gyles CL (1991). Escherichia coli cytotoxins and enterotoxins. Canadian Journal of Microbiology, 38: 734-746. 